\title{
ZOOLOGY IN NIGERIA
}

\author{
ECOLOGY OF LAGOS LAGOON
}

\begin{abstract}
HE University College of Nigeria has achieved a standing among the university institutions of the Commonwealth which few even among the most visionary spirits would have dared to hope for at the time of its foundation little more than ten years ago in a forest clearing at Ibadan. Students recruited from a country where there are few secondary schools have been enabled to pursue courses for honours degrees in a wide range of subjects and disciplines within the Faculties of Arts, Science, Agriculture and Medicine, and the standards achieved by them are those which the University of London, with which the College is in special relationship, requires of its honours students. That the College should have produced a body of graduates ready to take their places as administrators and teachers in a country soon to achieve independence is a tribute alike to the innate abilities of the Nigerian student and to the sound and imaginative teaching of the professors and lecturers who, over the years, have staffed the several departments of the College. Nor in these formative years has the prosecution of research been neglected and there has recently been published, in the Philosophical Transactions of the Royal Society, a series of papers* by Prof. J. E. Webb (two of them jointly with Dr. M. B. Hill), of the Department of Zoology, which will exemplify the kind of work which is being done and which, while born of and descriptive of West African conditions, probes deeply and with discernment into problems of fundamental and more general biological interest.
\end{abstract}

The papers are concerned primarily with the lifehistory and ecological requirements of the Nigerian lancelet, Branchiostoma nigeriense Webb, one of the many species contained within the group of the Cephalochordata the structure and development of which show them to stand very close to the ancestral stock of the vertebrates. The observations range in their scope from considerations of physical geography and coastal morphology to an analysis of the significance to animals of the size and shape of sand grains, without, however, ever losing its essential unitary character as an ecological investigation.

Lagoon systems occur on the Guinea Coast, within the general areas of the Ivory Coast, Togoland and Dahomey-Western Nigeria. They are formed behind barrier beaches of sand, the sand drifting from west to east along the beaches and offshore under the action of obliquely breaking waves developed under the predominantly south-westerly winds. Lagoons are formed by the seaward advance of the barrier beach or by enclosure by outwardly growing spits curved at the tips to form offshore bars. The lagoons may remain filled with water by virtue of river drainage or access to the sea. There is, however, a tendency for them gradually to fill with sediment,

* Phil. Trans. Roy. Soc., B, 241 (1958). The Ecology of Lagos Lagoon: T, J. E. Webb, The Lagoons of the Guinea Coast, pp. 307318; II, M. B. Hill and J. E. Webb, The Topography and Physical $\mathrm{J}$. $\mathrm{E}$. Webb, The Life Fistory of Branchiostoma nigeriense Webb, pp. 335-353; IV, M. B. Hill and J. E. Webb, On the Reactions of Branchiostoma nigeriense Webb to its Environment, pp. 355-391; V,
J. E. Webb, Some Physical Properties of Lagoon Deposits, pp. $393-419$. first to become swamps and then dry land. Aerial photographs show that the cycle has been repeated many (about twenty) times in the 25,000 years of the post-glacial history of the Guinea Coast. Narrow bands of sparse vegetation alternating with broader zones of more luxuriant growth mark, respectively, the lines of former sand barriers and of lagoon deposits.

The Lagos lagoon system is open to the sea by narrow channels and receives the drainage water from some 40,000 square miles of forest country. In the drier months from December to March higher salinities rising from about 10 to 30 per mille prevail, whereas with the coming of the rains the salinity falls sharply to give brackish or fresh conditions which tend to persist with brief intermissions from about April to December. It is against this background of changing salinities that the appearances and disappearances of Branchiostoma within the waters and bottom deposits of the lagoon must be viewed.

Laboratory experiments show that the lancelets tolerate changes in temperature greater than those normally encountered within the lagoon but that they die in less than a day's immersion in water of less than 13 per mille salinity. They are, in fact, absent from the lagoon from about mid-May to mid-December, when the salinity is $\mathbf{1 3}$ per mille. By mid-December conditions are again favourable for restocking of the lagoon from the persistent populations of lancelets of the outside waters. These latter were found to spawn from about August to October and to give rise to pelagic Iarvæ ready to seek the bottom and to metamorphose at the earliest some eleven weeks after fertilization, a tally being kept of the length of the larvæ and of the number of their gill pouches at the different ages. Larval life can be extended to twenty weeks or so if a suitable substratum is not available for settlement. Re-population of suitable lagoon deposits can then begin at the moment that the rise in salinity of the lagoon water permits of survival of larvæ drifted in from the sea. Once settlement has been achieved, the lancelets remain in the deposits until killed off in May by the fall in salinity following upon the onset of the March rains. In the meantime, a fow of the resident population will have spawned: the young are, however, short-lived, being killed by the influx of fresh water while still in the pelagic phase or shortly after metamorphosis.

The various aspects of these successive events are examined in detail. None is of more interest than the observations and experiments which bear on the substratum requirements of the metamorphosing and adult lancelets. In Nature, animals only occur in coarse sand containing 25 per cent of particles smaller than $0.2 \mathrm{~mm}$. in diameter and in which the finer silts bulk less than 1.5 per cent. While, in laboratory tests, a few animals would settle in soils containing rather more of the fine sand or of the silt, they did not long remain viable. Moreover, it was only in the coarse, open sands that they burrowed normally; in mixtures of progressively finer particles they remained 
partially buried or rested on the surface. But particle-size is not all. Smooth-grained mixtures are sought after, sharp particles avoided; again, sands with silt or organic matter in excess of a certain amount are not favoured, but neither are those which lack micro-organisms on the surfaces of the grains. It is shown that the particular size-range of particle mixtures chosen by the lancelets are those with a high porosity, that is to say, they have a system of canal spaces within which water may circulate freely.
Thus, in the event, the lancelets select substrata by their texture, but benefit by other propertins dependent on texture, such as free drainage.

The community concept, in so far as it applies to animals living in the deposits of the ocean floor, has long been known to be founded upon the selectioa by animals of soils of varying texture and particle size. Few investigations in recent years have been more revealing of the bases of this selection than those described in the last of the five papers here reviewed.
J. E. Smitr

\section{IMMUNOLOGICAL ASPECTS OF ALLERGIC DISORDERS}

"I MMUNOLOGICAL Aspects of Allergic Disorders" was the subject of the symposium of the autumn meeting of the British Society for Immunology, held jointly with the British Association of Allergists, at the Welleome Building, London, on November 14.

A. W. Frankland introduced the subject as a clinician engaged in the treatment of 'allergic' disorders, for which antigen-antibody reactions are considered responsible. Seasonal pollen asthma, the least complicated allergic disease, responds equally well in 90 per cent of subjects to pre-seasonal treatment with a high dosage of an extract of the pollen of a single grass as with extracts of mixed grass, illustrating the need for studies of pollen antigens. A beneficial effect, however, is also found in between one-third and one-half of the patients treated with saline injections.

The significance of reactions to skin tests showing the presence of reaginic antibodies capable of sensitizing the skin requires clinical confirmation. In 50 per cent of subjects sensitive to pollen skin tests, observed over a period of ten years, clinical sensitivity does not appear to become important. Inhalation tests may confirm the presence of clinical sensitivity.

The clear description of allergic reactions is desir. able. Immediate reactions are seen in pollen sensitivity; delayed reactions are of the tuberculin type. An unexplained relationship between these is present in reactions to insect bites. The first bites are usually innocuous, but after a time they may excite reactions of the delayed type. At a later stage, reactions of the immediate type appear, and still later, in some cases, there may be a complete absence of reaction to the bites.

R. Augustin, in a paper entitled "Allergens and othor Pollen Antigens", reported her investigations into the relationship of grass pollen antigens, which excite in rabbits the production of precipitating antibodies, and those grass pollen antigens, which are allergenic for man, reacting with the reaginic but non-precipitating antibodies which sensitize the skin, as shown by reactions to skin tests. The complicated pattern of antigen - antibody precipitation lines produced in agar-gel diffusion tosts with rabbit antisera were studied for their relevance to allergenic activity in skin tests on man. Enzymic and other studies showed that the antigens of timothy and cocksfoot pollen that were most highly electrically charged were not significantly related to skin-test allergens. The main allergens were found in those antigens having the electrophoretic mobilities and salting out properties of human serum $\alpha$ - and $\beta$-globulins. These antigens, on one hand, were precipitated with rabbit antiserum and, on the other, accounted for almost all the allergenic activity in man. The concentrated fractions obtained in this way contained 10-100 million Noon units/mgm. ( $1 \mathrm{mgm}$. pollen equals 1,000 Noon units by definition). Coupled preparations of this active allergenic material with red cell stromata and hide powder (Baird and Tatlock) were effective in removing, specifically, the reaginic antibodies from the serum, as shown by passive transfer tests, thus providing a method for demonstrating the presence of reagins.

J. G. Feinberg and H. Grayson discussed the results of "A New Look at the Antibodies to so-called 'Common' Antigens of Grass Pollens". Using antibody gradients and eccentric patterns of precipitation, they showed that rabbit antibodies to pollens have a greater affinity for homospecific than for heterospecific pollens. A similar but greater homospecificity is shown with rabbit antisera to ovalbumin and ovalbumin tagged by means of arsenilic acid. It was suggested that pollen treatment should be based on homospecific pollen allergens.

Some observations on the antibodies related to ragweed pollen were discussed by $B$. Rose, who with Sehon and his colleagues have found that there are four antibodies in the serum of sensitive patients. Erythrocytes coated with antigen provided a highly sensitive and specific method for demonstrating nonprecipitating antibodies. Two of the antibodies found were skin-sensitizing, one was a blocking antibody, and one a hæmagglutinating antibody. The blocking antibody was found in the slow-moving $\gamma_{2}$-globulin and the skin-sensitizing antibody in the fast-moving $\gamma_{1}$-globulin. The skin-sensitizing antibody also moved with the fast-sedimenting $S 19$ fraction. The hæmagglutinating antibodies are considered to be similar to the ordinary divalent antibodies and were found in all serum fractions con. taining skin-sensitizing and/or blocking antibodies.

M. Loveless discussed the reproducibility and practical value of the conjunctival test for estimating the degree of hypersensitivity to ragweed pollen. Reactions to increasing concentrations were observed, and a good correlation was found between the degree of hypersensitivity and the titre of blocking antibody present in the serum after treatment by injection. The conjunctival test was used as a guide to the safe dosage of pollen for injection in a 'repository' form, in emulsion of liquid paraffin and 'Arlacel'. Such a guide is necessary since the dosage of pollen in the limited number of injections of repository required is far higher than the initial doses of aqueous extracts used for conventional methods of pollen treatment. 